\title{
The Lecithinase of Bacillus cereus and its Comparison with Clostridium welchii $\alpha$-toxin
}

\author{
H. P. CHU \\ Institute of Animal Pathology, University of Cambridge
}

SUMMARY: Bacillus cereus and B. mycoides produce lecithinases which split lecithin into phosphorylcholine and a diglyceride in the same way as the lecithinase ( $\alpha$-toxin) of Clostridium welchii. These enzymes also possess most of the biological activities associated with $\mathrm{Cl}$. welchii $\alpha$-toxin, e.g. produce the Nagler reaction and the egg-yolk reaction, lyse red blood cells, and are dermonecrotizing and lethal.

The enzymes are activated by $\mathrm{Ca}$ and $\mathrm{Mg}$ ions, but inhibited by $\mathrm{Na}, \mathrm{K}, \mathrm{NH}_{4}$ ferric and $\mathrm{Al}$ ions. Optimal enzyme activity requires the presence of $\mathrm{Ca}$ ions within a narrow range of concentration of $1-4 \times 10^{-3} \mathrm{M}$. It is interesting that at this concentration of $\mathrm{Ca}$ ion lecithin flocculates most readily from its emulsion. The enzyme thus seems to have a maximal affinity for lecithin when the latter adsorbs an optimal amount of $\mathrm{Ca}$ ion in reaching its isoelectric point.

Like the $\mathrm{Cl}$. reelchii lecithinase, the $\boldsymbol{B}$. cereus lecithinase is fairly resistant to heat. The lysis of red blood cells and the hydrolysis of free lecithin by $B$. cereus lecithinase was strongly inhibited by normal sera of all the animals tested. But when lecithin was bound in egg-yolk lipoproteins, its hydrolysis by the enzyme was unaffected by normal serum. Specific serum, on the other hand, was capable of inhibiting the hydrolysis of both free lecithin and protein-bound lecithin. The $B$. cereus and $B$. mycoides lecithinases are immunologically related, but they are not so related to Cl. welchii lecithinase.

In a previous communication (McGaughey \& Chu, 1948) it was reported that, in the Bacillus group, Bacillus cereus, B. mycoides and B. anthracis were able to produce an egg-yolk reaction similar to that caused by Clostridium welchii $\alpha$-toxin. In the case of $\mathrm{Cl}$. welchii $\alpha$-toxin, the reaction was found to be due to the action of a lecithinase which splits lecithin into phosphorylcholine and diglyceride (Macfarlane \& Knight, 1941). A similar type of lecithinase has now been demonstrated in $\boldsymbol{B}$. cereus and $\boldsymbol{B}$. mycoides, and the activity also runs parallel with the yolk reactivity. In view of the close correlation between the lecithinase activity and the haemolytic, necrotic and lethal activities of $C l$. welchii $\alpha$-toxin, it was considered interesting to see whether the lecithinases obtained from these new sources and causing the same biochemical reaction on the substrate lecithin also possess the biological properties of the $\mathrm{Cl}$. welchii lecithinase.

\section{MATERIALS AND METHODS}

Cultures. Although many strains of B. cereus, B. mycoides and B. anthracis were used, for most of the work the enzyme was prepared from a strain of B. cereus (N.C.T.C. 945).

Preparation of lecithin. Lecithin was prepared and purified by the methods of Maclean \& Maclean (1927) and Welch (1945). Fresh egg yolks were extracted with several changes of ethanol. The ethanol extract was evaporated to dryness in vacuo and taken up in a small volume of ether. Crude phospholipids were precipitated 
from the ethereal solution with excess of acetone. The precipitate was taken up again in ether and kept in the refrigerator to allow sphinomyelin and galactolipin to separate out. After centrifuging, the clear ethereal solution was again treated with acetone and the process was repeated three times. Finally, the acetone precipitate, which contained chiefly lecithin and cephalin, was taken up in absolute ethanol. After standing in the refrigerator overnight, the cephalin which precipitated was removed by centrifugation. The purification was repeated until the product gave a perfectly clear solution in ice-cold ether or ethanol.

As lecithin is very unstable in air, it was found convenient to make a thick emulsion of the product as soon as it was prepared and to distribute it in fixed quantities, usually $250 \mathrm{mg}$., in small ampoules. They were then dried from the frozen state and sealed in vacuo. Lecithin kept in this form remained apparently unchanged for a long time. For use, the contents of an ampoule were washed out with water and diluted to the required volume. Lecithin kept in this form emulsifies very readily. The product generally contained 1.95-2 $\% \mathrm{~N}, 3 \cdot 75-3.9 \% \mathrm{P}, 13 \cdot 8-14 \cdot 2 \%$ choline with a molecular ratio of $P$ and choline 1:0.95-0.97.

Preparation of cephalin. Cephalin was prepared from sheep brain according to Maclean \& Maclean (1927). The product contained 3.76 \% P but no choline. It was not hydrolysed by $\mathrm{Cl}$. welchii lecithinase, and was thus practically free from lecithin.

Preparation of lipovitellin and lipovitellenin. Lipovitellin and lipovitellenin, the two egg-yolk lipoproteins, were prepared according to Alderton \& Fevold (1945) and Fevold \& Lausten (1946). The former contains 16-18\% and the latter 35-40\% of phospholipins, of which about $80 \%$ is lecithin.

Chemical analysis. Total $\mathbf{P}$ was determined photoelectro-colorimetrically by Brigg's method after ashing with $\mathrm{H}_{2} \mathrm{SO}_{4}$ and $\mathrm{HNO}_{3}$. N was estimated by the micro-Kjeldahl method and $\mathrm{Ca}$ by precipitation as oxalate and permanganate titration. For the estimation of choline, a modification of Beattie's reineckate method (Glick, 1944) was used.

Clostridium welchii $\alpha$-toxin. The $C l$. welchii $\alpha$-toxin used in this investigation was a glycerinated preparation containing 2800 lecithinase units (Macfarlane \& Knight, 1941) per ml., kindly supplied by Dr van Heyningen (1941 b).

Measurement of the lecithinase activity. Like $C l$. welchii lecithinase, $B$. cereus lecithinase splits lecithin into acid-soluble phosphorylcholine, and the rate of increase of acid-soluble phosphate also serves as a convenient measure of the enzyme activity. The method employed was essentially the same as that used for $C l$. welchii lecithinase (Macfarlane \& Knight, 1941). The reaction mixtures were made up with $1 \mathrm{ml}$. $0.05 \mathrm{~m}$ borate buffer $\mathrm{pH} 7 \cdot 1 ; 0.1 \mathrm{ml} .0 .1 \mathrm{M}-\mathrm{CaCl}_{2}$ (for Cl. welchii lecithinase $0.2 \mathrm{ml}$. was used); aqueous solution of enzyme and distilled water to $3 \mathrm{ml}$. After this mixture had been warmed to $37^{\circ}, 1 \mathrm{ml}$. of a $2.5 \%$ lecithin emulsion at the same temperature was added from a $1 \mathrm{ml}$. blow-out pipette to ensure an immediate mixing. The reaction was stopped after $15 \mathrm{~min}$. incubation at $37^{\circ}$ by the addition of $1 \mathrm{ml} .20 \%$ trichloroacetic acid, which also flocculated the undecomposed lecithin. The mixture was then filtered through a no. 50 Whatman filter-paper and the total phosphate in the filtrate estimated. The enzyme activity in the following experiments was generally expressed as $\mathrm{mg}$. of acid-soluble phosphate liberated from $25 \mathrm{mg}$. of lecithin in $15 \mathrm{~min}$. at $37^{\circ}$ and one arbitrary unit of lecithinase was defined as that amount of enzyme which under the above conditions would catalyse the production of $\mathbf{0} \cdot \mathbf{1} \mathrm{mg}$. acid-soluble $\mathbf{P}$.

Measurement of the egg-yolk reaction. The production of opalescence in eggyolk extract by the action of lecithinase was measured by a modification of 
van Heyningen's (1941 a) method. The standard conditions finally adopted were as follows: $1 \mathrm{ml}$. enzyme diluted in water, $1 \mathrm{ml} .0 .05 \mathrm{M}$ borate buffer (pH 7.1) and $2 \mathrm{ml}$. distilled water were put in a test-tube or preferably in the cups of the photoelectric colorimeter, and warmed to $37^{\circ} ; 2 \mathrm{ml} .5 \%$ egg-yolk extract at the same temperature were then added. After $15 \mathrm{~min}$. at $37^{\circ}$ the turbidity was read in a photoelectric colorimeter fitted with a grey filter.

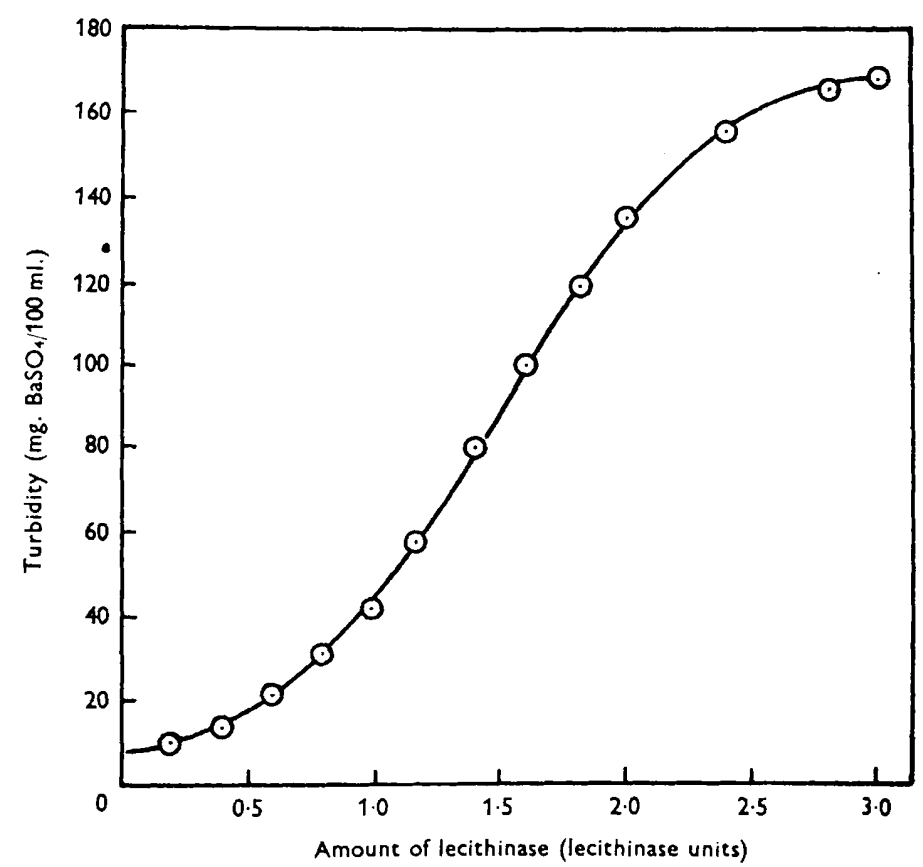

Fig. 1. The effect of lecithinase concentration on development of turbidity in egg-yolk extract. Reaction mixture: amount of lecithinase indicated above, $1 \mathrm{ml}$; borate buffer $\mathrm{pH} 7 \cdot 1 ; 2 \mathrm{ml}$. yolk saline; water to $6 \mathrm{ml}$.; reaction time $15 \mathrm{~min}$. at $37^{\circ}$.

In the photoelectric colorimeter (King, 1946) the reading ('extinction coefficient $\mathbf{E}$ ' multiplied by 100 ) is not a linear function of the turbidity, especially when the reading is greater than 30 . For this reason the turbidities were read from a standard curve prepared by plotting the colorimeter readings of a series of suspensions of $\mathrm{BaSO}_{4}$. Using this curve the turbidity of a given egg-yolk reaction mixture was expressed in terms of its equivalent $\mathrm{BaSO}_{4}$ concentration. The standard $\mathrm{BaSO}_{4}$ suspensions were prepared as follows: a stock suspension of $\mathrm{BaSO}_{4}$ was prepared by adding $1 \%(\mathrm{v} / \mathrm{v})$ conc. $\mathrm{H}_{2} \mathrm{SO}_{4}$ to $20 \mathrm{ml} .1 \%$ (w/v) $\mathrm{BaCl}_{2}$ with stirring to a total volume of $100 \mathrm{ml}$. The resultant suspension was calculated to contain $224 \mathrm{mg}$. of $\mathrm{BaSO}_{4} / 100 \mathrm{ml}$. A series of suspensions containing $1-200 \mathrm{mg} . \mathrm{BaSO}_{4} / 100 \mathrm{ml}$. were then prepared by diluting the stock $\mathrm{BaSO}_{4}$ suspension with $1 \%$ conc. $\mathrm{H}_{2} \mathrm{SO}_{4}$.

A dry enzyme preparation containing 3 lecithinase units per mg. was used as the standard for the egg-yolk turbidity estimation. Fig. 1 shows the turbidities produced in $15 \mathrm{~min}$. by $0-3$ units of lecithinase under the above 
conditions. It can be seen that in the region of from 1 to 2 units, the turbidity is a linear function of the enzyme concentration.

It must be emphasized that under the above standard conditions the final reaction mixture (total volume of $6 \mathrm{ml}$.), is $0.3 \%$ with respect to $\mathrm{NaCl}$ and contains no $\mathrm{Ca}$ ion except that present in the egg yolk. In the case of $\mathrm{Cl}$. welchii sufficient $\mathrm{Ca}$ ion is added to a final concentration of $0.005 \mathrm{M}$. A slight change in the salt concentration has a great influence on the turbidity produced. As the absolute turbidity produced by a certain amount of enzyme is influenced by a number of conditions which can hardly be identical in two occasions, it is advisable to run a few standards with each set of estimations. When the enzyme to be estimated is present in a complicated medium the standard enzyme preparation must be diluted with the same medium so that the effect of the salts and other substances present in the medium can be eliminated.

Measurement of haemolytic activity. Haemolytic activity was measured by modifications of the methods of Herbert (1941) and van Heyningen (1941 b). Decreasing amounts of haemolysin diluted to a total volume of $2 \mathrm{ml}$. with borate buffer saline ( $\mathrm{pH} \mathrm{7 \cdot 1)}$ containing $1^{-4} \mathrm{M}^{-\mathrm{Ca}^{++}}$were incubated with $1 \mathrm{ml}$. of a washed sheep red-cell suspension standardized to contain $20 \mathrm{mg}$. haemoglobin $/ \mathrm{ml}$. (equivalent to $c .6 \%$ cell suspension). After $1 \mathrm{hr}$. at $37^{\circ}$ the reaction was stopped by the addition of $7 \mathrm{ml}$. of normal saline containing $5 \%$ of normal horse serum, which was found to inhibit strongly the haemolytic activity of $B$. cereus. The unhaemolysed cells were then removed by centrifugation and the percentage haemolysis was estimated from the haemoglobin content of the supernatant fluid in a photo-electric colorimeter fitted with a green filter. The colorimeter readings were transformed directly into percentage haemolysis by reference to a standard curve prepared with a series of standard haemoglobin solutions. This curve was also used for the standardization of the red-cells suspension.

An arbitrary haemolytic (H.U.) unit is defined as the amount of haemolysin causing $50 \%$ haemolysis of $1 \mathrm{ml}$. suspension of sheep red blood cells containing $20 \mathrm{mg}$. haemoglobin after $1 \mathrm{hr}$. at $37^{\circ}$. Fig. 2 shows the degree of haemolysis produced by $0.5-3.5$ H.U. of $B$. cereus haemolysin. The shape of the curve is similar to that of streptolysin $\mathrm{O}$ (Herbert, 1941) and $\mathrm{Cl}$. welchii $\alpha$-toxin (van Heyningen, 1941 b).

\section{RESULTS}

\section{Concentration of the enzyme}

A $20 \mathrm{hr}$. nutrient broth culture of B. cereus was used as a source of the enzyme. To the culture filtrate, which generally contained 1-2 units of lecithinase, ammonium sulphate was added slowly with stirring to two-thirds saturation. The precipitate, which contained most of the enzyme, was then redissolved in one-twentieth of its original volume of water. To this solution half a volume of saturated ammonium sulphate solution was added and the resultant dark brown sticky precipitate was centrifuged off. The clear supernatant was dialysed against running tap water for $8 \mathrm{hr}$., and then against several changes of distilled water at $2^{\circ}$ for $24 \mathrm{hr}$. The dialysed solution was either dried to 
a solid in vacuo or concentrated by dialysing against $50 \%$ aqueous glycerol. The latter preparation retained its enzymic activity unchanged for over $1 \frac{1}{2}$ years. The glycerinated solution generally contained 50-80 lecithinase units per $\mathrm{ml}$. and the dry preparation about three lecithinase units per mg. The discarded fractions precipitated by one-third saturation, and by more than two-thirds saturation, with ammonium sulphate contained 0.02 or less lecithinase units per mg.

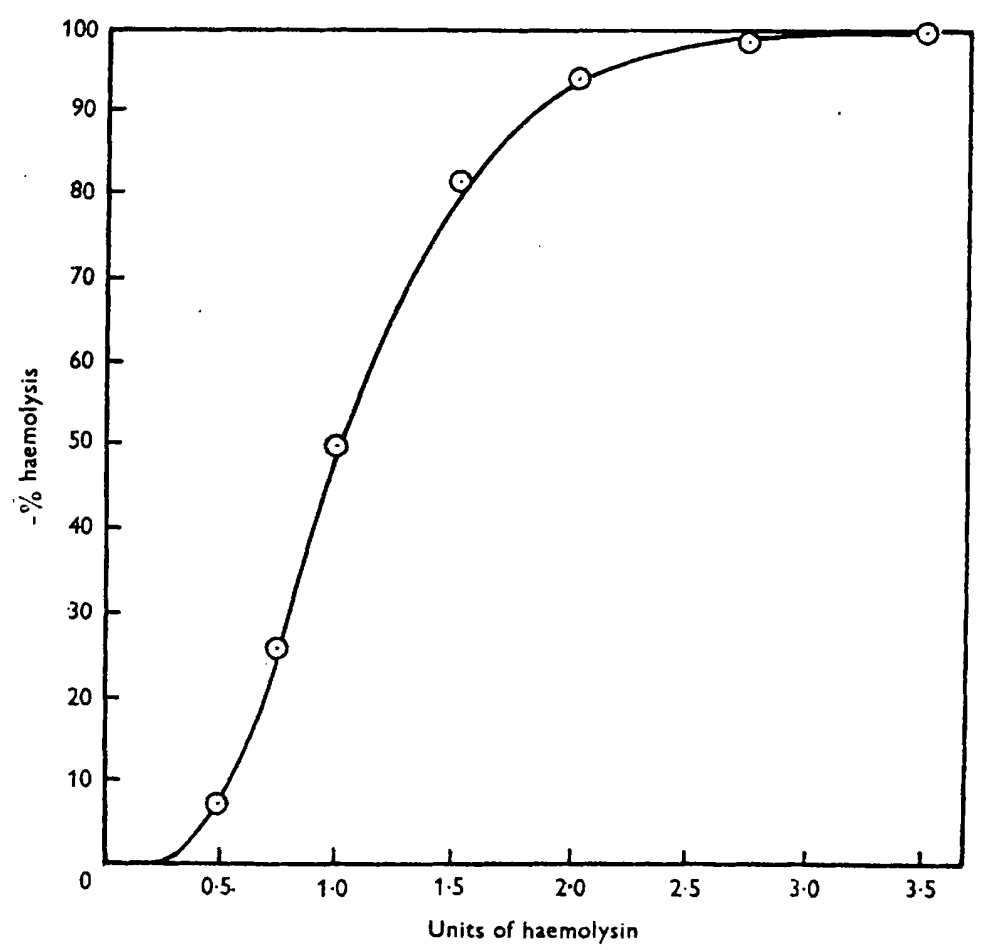

Fig. 2. Standard curve for titration of $B$. cereus haemolysin.

\section{Mode of hydrolysis of lecithin by Bacillus cereus lecithinase}

The mode of hydrolysis of lecithin by $\boldsymbol{B}$. cereus lecithinase was compared with that of $\mathrm{Cl}$. welchii lecithinase. Of three samples of $760 \mathrm{mg}$. of lecithin containing $30 \mathrm{mg}$. of $\mathrm{P}$, one was hydrolysed by $B$. cereus lecithinase, one by $\mathrm{Cl}$. welchii lecithinase and the third served as a control. The reaction mixtures were made up with distilled water to a total volume of $20 \mathrm{ml}$. and contained $0.005 \mathrm{M}-\mathrm{CaCl}_{2}$. On incubation the enzyme mixtures rapidly became acid and were frequently neutralized with $0 \cdot 1 \mathrm{~N}-\mathrm{NaOH}$ during the course of the hydrolysis. After $8 \mathrm{hr}$. at $37^{\circ}$ the enzyme mixtures became fairly clear with a layer of fat on the surface, while the control still remained milky. The mixtures were then extracted four times with ether, and the ethereal solutions were separated by centrifugation. The combined ethereal solutions were evaporated to dryness, and extracted with acetone. The residues from the ether extracts of the 
enzyme mixtures were almost completely soluble in acetone; that from the control mixture was completely insoluble, showing that most of the lecithin had been hydrolysed by the enzymes yielding acetone-soluble material. The acetone-soluble materials from both mixtures had the same acid value of $2 \cdot 0$, and thus appeared to be neutral fats.

Table 1. Comparison of hydrolysis of lecithin by Clostridium welchii lecithinase and Bacillus cereus lecithinase

\begin{tabular}{|c|c|c|c|}
\hline & $\begin{array}{c}\text { B. cereus } \\
\text { lecithinase }\end{array}$ & $\begin{array}{l}\text { Cl. rvelchii } \\
\text { lecithinase }\end{array}$ & $\begin{array}{c}\text { Control } \\
\text { (no enzyme) }\end{array}$ \\
\hline \multicolumn{4}{|l|}{ Before hydrolysis: } \\
\hline Lecithin (mg.) & 760 & 760 & 760 \\
\hline Total P (mg.) & $29 \cdot 9$ & $29 \cdot 9$ & $29 \cdot 9$ \\
\hline Total N (mg.) & $15 \cdot 4$ & $15 \cdot 4$ & $15 \cdot 4$ \\
\hline \multicolumn{4}{|l|}{ After hydrolysis : } \\
\hline \multicolumn{4}{|l|}{ (1) Water soluble products: } \\
\hline Total P (mg.) & $29 \cdot 0$ & $28 \cdot 5$ & 0.3 \\
\hline Total N (mg.) & $14 \cdot 5$ & $14 \cdot 0$ & $0 \cdot 15$ \\
\hline Inorganic $\mathbf{P}$ (mg.) & 0 & 0 & 0 \\
\hline Free choline (mg.) & $\mathbf{0}$ & 0 & 0 \\
\hline \multicolumn{4}{|l|}{ (2) Ether soluble products: } \\
\hline $\begin{array}{l}\text { Acetone soluble material } \\
\text { (neutral fat) (mg.) }\end{array}$ & $529 \cdot 6$ & $510 \cdot 0$ & $\mathbf{0}$ \\
\hline $\begin{array}{l}\text { Acetone insoluble material } \\
\text { (unhydrolysed lecithin) (mg.) }\end{array}$ & $20 \cdot 0$ & $31 \cdot 0$ & 720 \\
\hline
\end{tabular}

Table 2. The action of Bacillus cereus and Clostridium welchii lecithinases on free and protein-bound phospholipins

\begin{tabular}{|c|c|c|c|}
\hline \multirow[b]{2}{*}{ Substrate } & \multirow[b]{2}{*}{$\begin{array}{c}\text { Time of } \\
\text { incubation }\end{array}$} & \multicolumn{2}{|c|}{$\begin{array}{c}\text { Acid soluble } \mathbf{P} \text { (mg.) liberated } \\
\text { by the action of }\end{array}$} \\
\hline & & $\begin{array}{l}1 \mathrm{mg} \text {. B. cereus } \\
\text { lecithinase } \\
\text { preparation }\end{array}$ & $\begin{array}{l}1 / 900 \mathrm{ml} . \\
\text { Cl. welchii } \\
\text { lecithinase } \\
\text { preparation }\end{array}$ \\
\hline $25 \mathrm{mg}$. of free lecithin & $\left\{\begin{array}{c}15 \mathrm{~min} . \\
3 \mathrm{hr} .\end{array}\right.$ & $\begin{array}{l}0 \cdot 30 \\
0 \cdot 64\end{array}$ & $\begin{array}{l}0.30 \\
0.62\end{array}$ \\
\hline $\begin{array}{l}\mathbf{2 5} \mathrm{mg} \text {. of free phospholipins } \\
\text { extracted from lipovitellenin }\end{array}$ & $\left\{\begin{array}{c}15 \mathrm{~min} . \\
3 \mathrm{hr} .\end{array}\right.$ & $\begin{array}{l}0.31 \\
0 \cdot 65\end{array}$ & $\begin{array}{l}0.30 \\
0.61\end{array}$ \\
\hline $\left.\begin{array}{l}70 \mathrm{mg} \text {. of lipovitellenin con- } \\
\text { taining about } 25 \mathrm{mg} . \text { of bound } \\
\text { phospholipin }\end{array}\right\}$ & $\left\{\begin{array}{l}15 \mathrm{~min} . \\
3 \mathrm{hr} .\end{array}\right.$ & $\begin{array}{l}0 \cdot 15 \\
0 \cdot 34\end{array}$ & $\begin{array}{l}0.03 \\
0.05\end{array}$ \\
\hline
\end{tabular}

The aqueous solution from the two enzyme mixtures contained more than $95 \%$ of the original lecithin $\mathrm{P}$ in an organic form and an equivalent amount of $\mathbf{N}$ but no free choline. In the case of $\mathbf{C l}$. welchii the organic $\mathbf{P}$ compound was crystallized as Ca salt and identified as phosphorylcholine (Macfarlane \& Knight, 1941). By means of their technique $85 \mathrm{mg}$. of crystals were obtained from $B$. cereus lecithinase reaction mixture and $105 \mathrm{mg}$. from that of $\mathrm{Cl}$. welchii lecithinase. Analysis showed that their compositions were very similar and agreed fairly well with that required for crystalline $\mathrm{Ca}$ compound of phosphorylcholine. (Ca, 12.0 and $12.0 \% ; \mathrm{N}, 4.4$ and $4.3 \%$; total P, 8.8 and $9.0 \%$; 
free choline and inorganic phosphorus 0 ; first figures for the crystalline compound from $B$. cereus lecithinase reaction mixture and second figures for that from $\mathrm{Cl}$. welchii lecithinase mixture.) Both crystalline organic $\mathbf{P}$ compounds were rapidly hydrolysed by a bone phosphatase preparation free from diesterase (kindly supplied by Dr M. G. Macfarlane). Equivalent amounts of free choline and inorganic phosphate were liberated from the two crystalline compounds after the hydrolysis, i.e. both compounds were phosphorylcholine. The changes of the three reaction mixtures after incubation are shown in Table 3. It can be seen that $B$. cereus lecithinase acts on lecithin in the same way as $\mathrm{Cl}$. welchii lecithinase, in that neutral fat and phosphorylcholine are produced.

\section{Action of Bacillus cereus lecithinase on egg-yolk extract}

When egg-yolk extract was incubated with the enzyme preparation, there was a gradual increase of turbidity followed by formation of scum. Analysis of the reaction mixture showed a great increase of acid-soluble $\mathbf{P}$ as a result of the action of the lecithinase on the egg-yolk phospholipins. The close correlation of the lecithinase activity with the development of opalescence in egg-yolk extract was shown by the following experiment.

To a mixture of $10 \mathrm{ml}$. of diluted enzyme, $10 \mathrm{ml}$. of borate buffer $(\mathrm{pH} 7 \cdot 1)$ and $20 \mathrm{ml}$. of distilled water at $37^{\circ}, 20 \mathrm{ml}$. of yolk saline at the same temperature were added. Immediately and at intervals after mixing, the turbidities of $6 \mathrm{ml}$. samples were determined. As soon as each turbidity was read, $1 \mathrm{ml} .20 \%$ trichloracetic acid was added to stop the reaction and the total acid-soluble phosphate estimated. The rate of liberation of acid-soluble $\mathbf{P}$ and the development of turbidity were almost parallel. There is little doubt that the production of turbidity in egg-yolk extract in this case is due primarily to the lecithinase activity, but the quantitative development of the egg-yolk reaction is determined also by a number of conditions which must be well controlled when the egg-yolk reaction is used for the titration of lecithinase.

\section{The action of Bacillus cereus and Clostridium welchii lecithinases on egg-yolk lipoproteins}

Under the above experimental conditions $B$. cereus lecithinase preparation was more active in producing turbidity in egg-yolk extract than $\mathrm{Cl}$. welchii lecithinase. About 3 units of the latter is required to develop in egg-yolk extract a turbidity comparable to that produced by 1 unit of the former. As the eggyolk reaction, also known as the lecitho-vitellin (L.v.) reaction, is supposed to be due to the action of lecithinase on egg-yolk lipoproteins, it was considered interesting to see if these two lecithinases also vary in their activities against purified egg-yolk lipoproteins. Lipovitellenin, the egg-yolk lipoprotein containing more phospholipins and with less phosphorus in its protein part, was chosen for this purpose. The preparation used contained $1.5 \% \mathrm{P}, 9.9 \% \mathrm{~N}$, and $4.99 \%$ choline. It could be dissociated with ethanol and repeatedly extracted with ether and ethanol to give $63 \%$ vitellenin $(\mathrm{N}, 15 \cdot 4 \% ; \mathrm{P}, 0.23 \%$; choline, nil) and $36 \%$ phospholipin (N, $1.8 \%$, P, 3.54\%; choline, $11.1 \%$; 
choline $/ \mathbf{P}=\mathbf{0} \cdot 79 / 1)$. From the analysis it can be seen that about four-fifths of the phospholipin was choline-containing and that any cephalin present could not be more than one-fifth of the total phospholipin. As shown in Table 2, similar amounts of $B$. cereus and $C l$. welchii lecithinases, based on their rate of hydrolysis of free lecithin, also had about the same activity on the free phospholipin extracted from lipovitellenin, but varied very much in their activities against phospholipin bound in lipovitellenin. $\mathrm{Cl}$. welchii lecithinase appeared to be much less active against vitellenin-bound lecithin as compared with $B$. cereus lecithinase. This might also account partially for its weaker

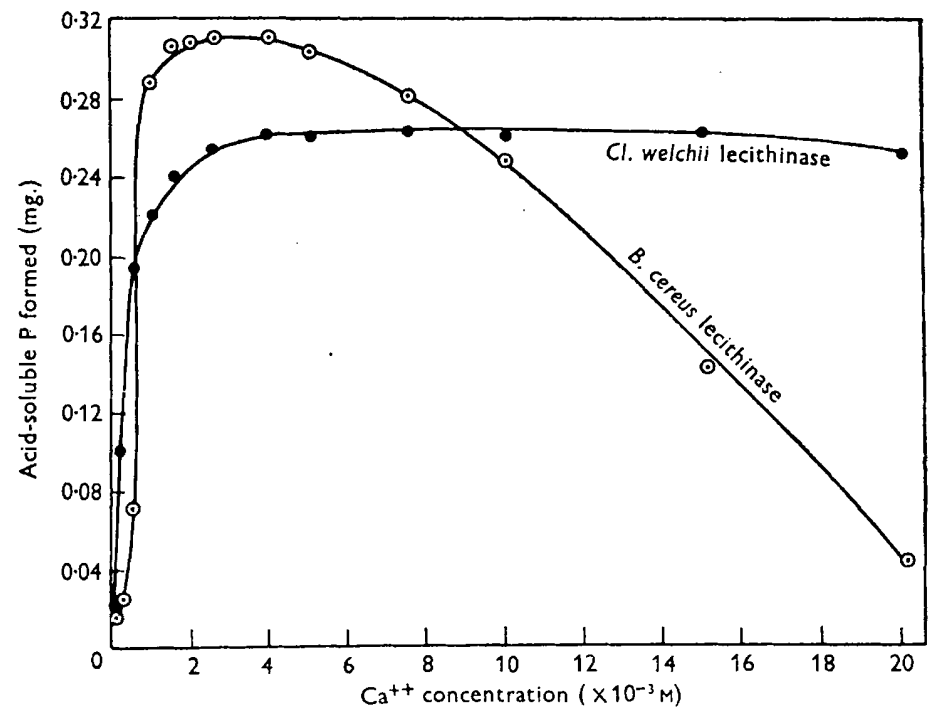

Fig. 3. Effect of $\mathrm{Ca}$ concentration on hydrolysis of free lecithin by $B$. cereus and $\mathrm{Cl}$. reelchii lecithinases. Reaction mixture: $1 \mathrm{mg}$. B. cereus lecithinase preparation or $0.001 \mathrm{ml}$. Cl. welchii $\alpha$-toxin; $1 \mathrm{ml}$. borate buffer $\mathrm{pH} 7.1 ; 1 \mathrm{ml} .2 .5 \%$ lecithin; $0-0.8 \mathrm{ml}$. $0.1 \mathrm{M}-\mathrm{CaCl}_{2}$; water to $4 \mathrm{ml}$; ; reaction time $15 \mathrm{~min}$. at $37^{\circ}$.

activity on egg-yolk extract. As B. cereus lecithinase preparation also acts on cephalin, its relatively higher activity on lipovitellenin, as measured by the amount of acid-soluble $\mathbf{P}$ liberated, might be due to the additional effect of cephalinase. But estimation of the choline content of the hydrolysis products showed that over $90 \%$ of the acid-soluble $\mathrm{P}$ was, in fact, liberated from lecithin.

\section{Characteristics of Bacillus cereus lecithinase}

The effect of $\mathrm{Ca}$ and $\mathrm{Na}$ ions on the lecithinase activity. Like $\mathrm{Cl}$. welchii lecithinase, the activity of $\boldsymbol{B}$. cereus lecithinase is greatly affected by $\mathrm{Ca}$ ion. Fig. 3 compares the effects of $\mathrm{Ca}$ ion on $\mathbf{B}$. cereus and $\mathbf{C l}$. welchii lecithinases. The latter has a wide range of optimal $\mathrm{Ca}$ concentration, whereas the activity of the former is maximal in the narrow range of $1-4 \times 10^{-3} \mathrm{M}-\mathrm{Ca}$. As lecithin is readily precipitated from an emulsion by $\mathrm{Ca}$ salts, it was first thought that the inhibitory effect of $\mathrm{Ca}$ ion at higher concentrations might be simply due 
to precipitation of lecithin. In order to elucidate this, the effect of $\mathrm{Ca}$ ion on the lecithin emulsion itself was investigated. It was expected that lecithin emulsion would be stable at the concentration of $\mathrm{Ca}$ ion optimal for the lecithinase activity and precipitation might take place at a higher concentration. Contrary to these expectations, lecithin emulsion was found to be most unstable in the presence of $1-4 \times 10^{-3} \mathrm{M}-\mathrm{Ca}$, which is the optimal concentration for the activity of $\boldsymbol{B}$. cereus lecithinase. This correlation is shown in Table 3.

Table 3. The effect of calcium on the flocculation of lecithin and the activity of Bacillus cereus lecithinase

\begin{tabular}{|c|c|c|c|c|c|c|c|c|}
\hline & \multicolumn{8}{|c|}{ Concentration of $\mathrm{Ca}\left(10^{-3} \mathrm{M}\right)$} \\
\hline & 25 & 10 & 5 & $2 \cdot 5$ & $1 \cdot 25$ & 0.5 & 0.25 & 0 \\
\hline $\begin{array}{l}\text { Rate of flocculation* } \\
\text { of lecithin }\end{array}$ & - & - & ++ & ++ & +++ & + & - & - \\
\hline $\begin{array}{l}\text { Lecithinase activity } \dagger \\
\text { (mg. P liberated) }\end{array}$ & 0.030 & $0 \cdot 230$ & $0 \cdot 300$ & $0 \cdot 312$ & $0 \cdot 310$ & 0.075 & 0.024 & 0.022 \\
\hline
\end{tabular}

The fact that $B$. cereus lecithinase activity is greatest at the $\mathrm{Ca}$ ion concentration at which lecithin flocculates most readily from its emulsion suggests that the enzyme might have a maximal affinity for lecithin when the latter has absorbed an optimal amount of $\mathrm{Ca}$ ion in reaching its isoelectric point.

Although the hydrolysis of free phospholipins by $\boldsymbol{B}$. cereus lecithinase requires the presence of free $\mathrm{Ca}$ ion, the egg-yolk reaction and the hydrolysis of phospholipins bound in lipovitellenin were found to proceed with maximal velocity even in the presence of oxalate. The addition of $\mathrm{Ca}$ ion, in concentration as low as $10^{-3} \mathrm{M}$, greatly decreased these activities (see Fig. 4). The independence of $B$. cereus lecithinase of free $\mathrm{Ca}$ ion for the hydrolysis of phospholipin present in lipovitellenin might be due to a small amount of $\mathrm{Ca}$ $(0.08 \%)$ bound in the lipovitellenin which is not readily precipitated by oxalate and is sufficient to activate the enzyme. It is also possible that the combination of phospholipin with protein has so changed their configurations as to render $\mathrm{Ca}$ ion unnecessary for the action of the enzyme on the phospholipin.

Later, it was found that $\mathrm{Na}$ ion has a strong inhibitory action on the enzyme activity, the activity of the enzyme in physiological saline being only $5 \%$ of that in water. Fig. 5 shows the amount of acid-soluble $\mathbf{P}$ liberated from lecithin by a given amount of $\boldsymbol{B}$. cereus lecithinase at various concentrations of $\mathrm{Na}$ ion. A similar, but smaller effect was observed with $\mathrm{Cl}$. welchii lecithinase.

The effect of $\mathrm{pH}$. Since the enzyme activity is greatly affected by a small change in the $\mathrm{Na}$ concentration, and since sodium salt buffers of different $\mathrm{pH}$ generally vary in their $\mathrm{Na}$ content, it is necessary to equalize the final $\mathrm{Na}$ concentration of reaction mixtures containing buffers of different $\mathrm{pH}$, otherwise the enzyme activity might be influenced not only by the difference 


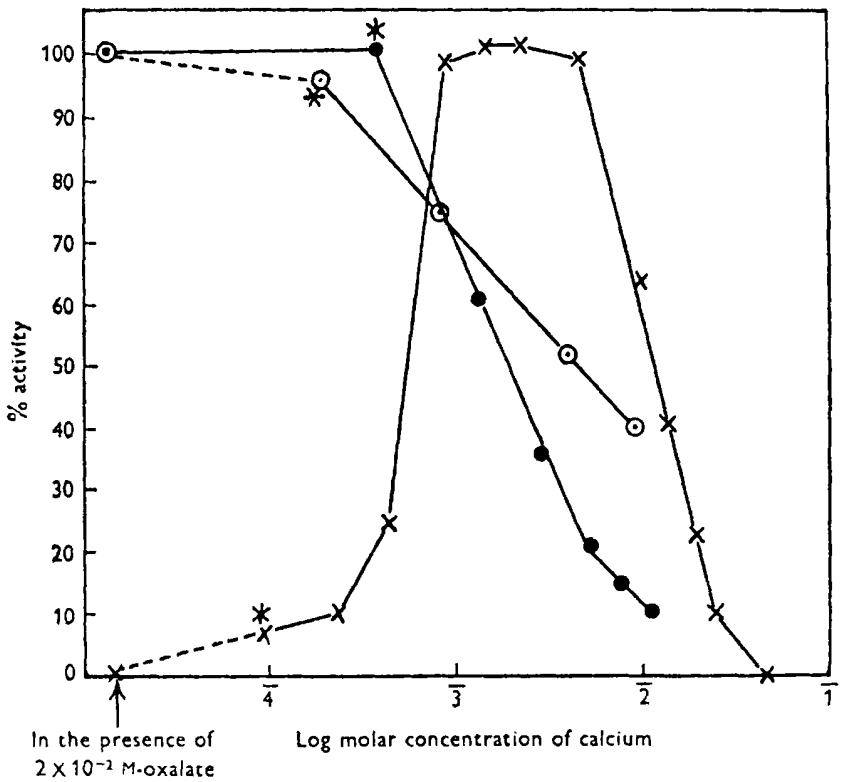

Fig. 4. The effect of Ca on hydrolysis of free and bound phospholipins by $B$. cereus lecithinase. $x-x-x$, hydrolysis of free lecithin; $\odot-\odot-\odot$, hydrolysis of phospholipins bound in lipovitellenin ; - - - , production of turbidity in egg-yolk extract. Percentage activity is calculated by assuming the maximal activity as $100 \%$. (No Ca was added to these reaction mixtures; the small amount of Ca present came from the enzyme and the substrate.)

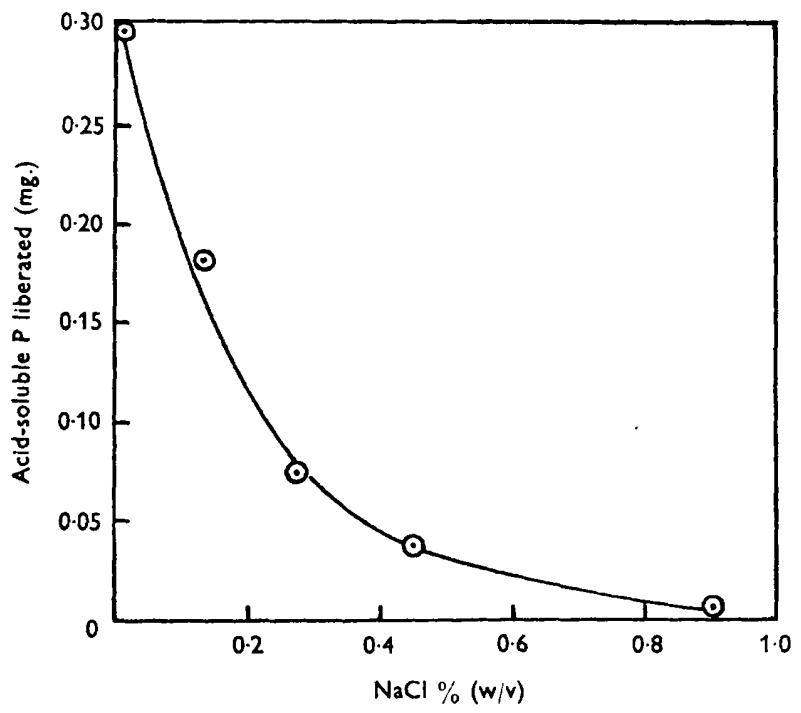

Fig. 5. The effect of $\mathrm{Na}$ concentration on lecithinase activity of $\mathrm{B}$. cereus. Reaction mixture: $1 \mathrm{mg}$. B. cereus lecithinase preparation; $1 \mathrm{ml}$. borate buffer $\mathrm{pH} 7 \cdot 1 ; 0 \cdot 1 \mathrm{ml} .0 \cdot 1 \mathrm{M}-\mathrm{CaCl}_{2}$; $1 \mathrm{ml} .2 .5 \%$ lecithin; $0-0.6 \mathrm{ml} .6 \%(\mathrm{w} / \mathrm{v}) \mathrm{NaCl}$; water to $4 \mathrm{ml}$; reaction time $15 \mathrm{~min}$. at $37^{\circ}$. 
of $\mathrm{pH}$, but also by the variation of the salt concentration. Fig. 6 compares the enzyme activities at various pH's with and without adjustment of the final $\mathrm{Na}$ concentration. Borate buffers were used for $\mathrm{pH} \mathrm{6 \cdot 7-9}$ and acetate buffer for $\mathrm{pH} 5 \cdot 7$. The final strength of the buffer in the reaction mixture is $0 \cdot 012 \mathrm{M}$. Although the optimal $\mathrm{pH}$ in both cases was around neutrality, the effect was greatly exaggerated in curve $I$, where the final salt concentrations were left unadjusted. This additional effect was doubtless due to the lower $\mathrm{Na}$ ion concentrations at $\mathrm{pH}$ 's near neutrality.

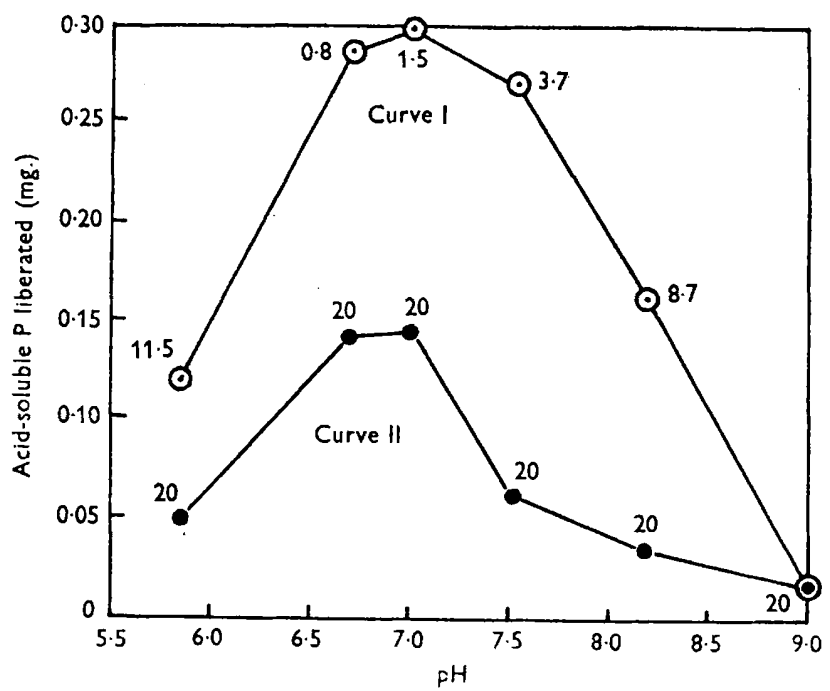

Fig. 6. The effect of $\mathrm{pH}$ on the activity of $B$. cereus lecithinase. Reaction mixture: $1 \mathrm{mg}$. B. cereus lecithinase preparation, $0.1 \mathrm{ml} .0 .1 \mathrm{M}-\mathrm{CaCl}_{2} ; 1 \mathrm{ml} .2 .5 \%$ lecithin; $1 \mathrm{ml} .0 \cdot 05 \mathrm{M}$ borate buffer $\mathrm{pH} 6 \cdot 7-9 \cdot 0$, or acetate buffer $\mathrm{pH} 5 \cdot 7$; water to $4 \mathrm{ml}$; reaction time $15 \mathrm{~min}$. at $37^{\circ}$. Figures on the curves indicate the calculated $\left[\mathrm{Na}^{+}\right]$of the reaction mixtures $\left(\times 10^{-3} \mathrm{M}\right)$. The variation of $\left[\mathrm{Na}^{+}\right]$at various $\mathrm{pH}$ 's as shown in curve 1 is due to the different $\mathrm{Na}$ content of the buffers. In curve $\mathrm{II}$, the $\left[\mathrm{Na}^{+}\right]$of the reaction mixture at various $\mathrm{pH}$ 's were all adjusted to that at $\mathrm{pH} 9$, i.e. $20 \times 10^{-3} \mathrm{M}$ by the addition of NaCl solution.

Effect of substrate concentration. Fig. 7 shows the effect of substrate concentration on the initial velocity of hydrolysis with a given concentration of enzyme. Since lecithin is present as a colloidal solution, it is difficult to calculate the Michaelis constant $(K m)$ for the enzyme. Following the method of calculation, as used by Zamecnik, Brewster \& Lipmann (1947) for $\mathrm{Cl}$. welchii lecithinase, and making similar assumptions, the $K m$ of $B$. cereus lecithinase is calculated to be $4 \cdot 8-5 \cdot 4 \times 10^{-3} \mathrm{M}$, which is near to that of $\mathrm{Cl}$. welchii lecithinase, viz. $5 \times 10^{-3} \mathrm{M}$.

Effect of enzyme concentration. Fig. 8 shows that the initial velocity of hydrolysis, as measured by determining the amount of acid-soluble $\mathbf{P}$ formed in 15 min., is directly proportional to the enzyme concentration over at least an eightfold range.

The stability of the enzyme. Like $C l$. welchii lecithinase, the $B$. cereus enzyme 


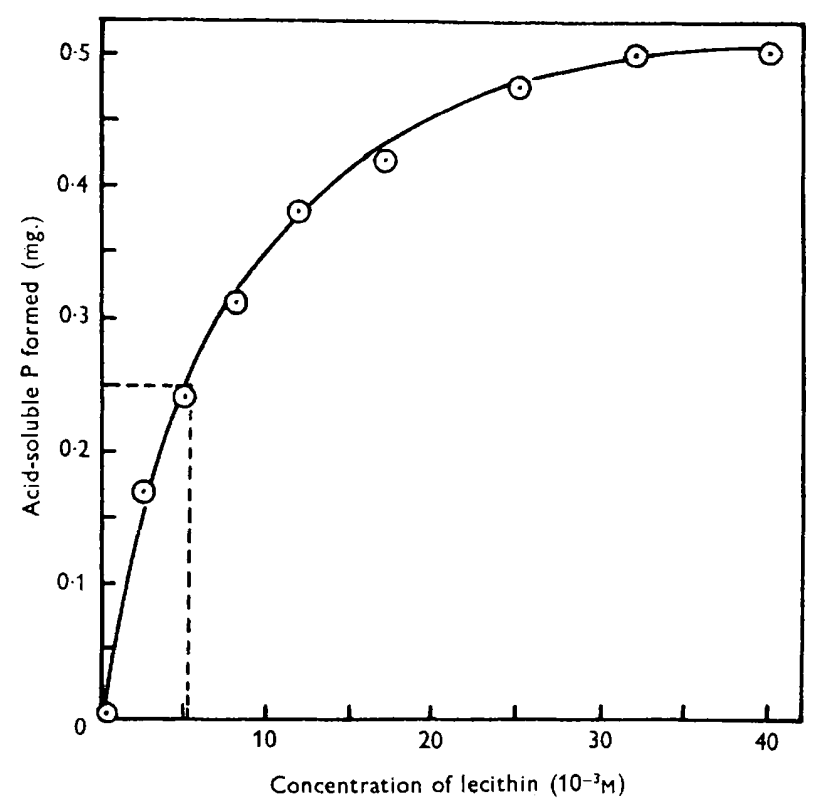

Fig. 7. The effect of substrate concentration. Enzyme concentration $0 \cdot 25 \mathrm{mg} . / \mathrm{ml}$.; $\mathrm{pH} \mathrm{r} \cdot 1$; total volume of reaction mixture $4 \mathrm{ml}$; ; reaction time $15 \mathrm{~min}$. at $37^{\circ}$.

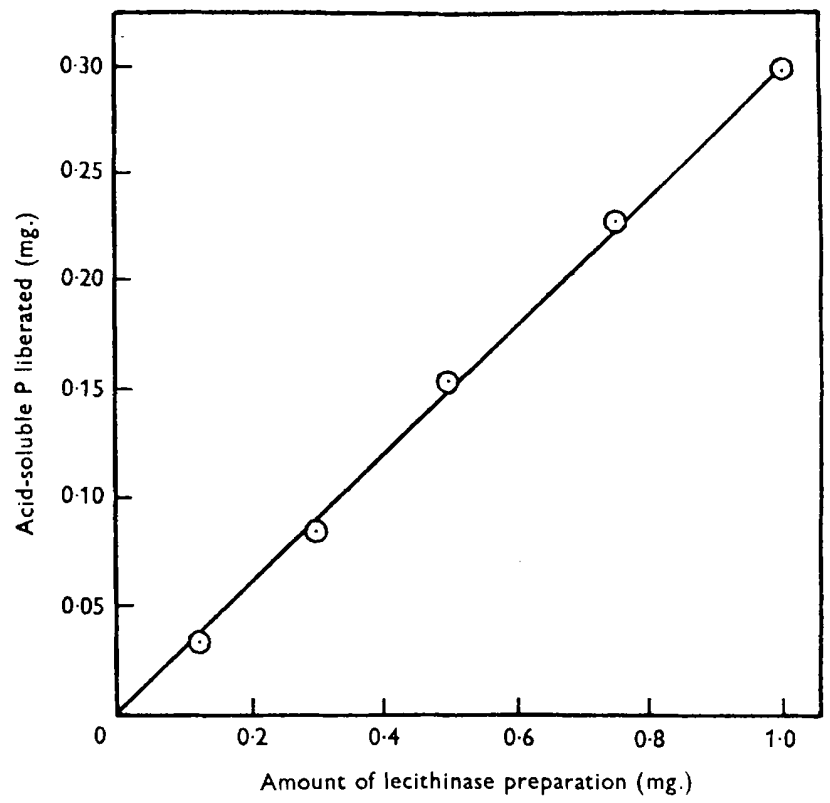

Fig. 8. The effect of enzyme concentration. Reaction mixture: $25 \mathrm{mg}$. lecithin; $1 \mathrm{ml}$.

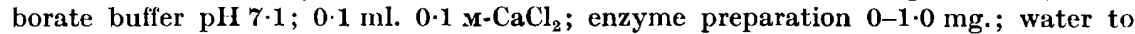
$4 \mathrm{ml}$; reaction time $15 \mathrm{~min}$. at $37^{\circ}$. 
is fairly heat stable. Heating the enzyme in $\mathrm{pH} \mathbf{7 \cdot \mathbf { 1 }}$ borate buffer for $\mathbf{3 0} \mathrm{min}$. at $60^{\circ}$ in a sealed tube destroyed only $20 \%$ of its activity, and $30 \%$ of its activity still remained after standing in boiling water for $10 \mathrm{~min}$. The enzyme is also resistant to oxidation; treatment with a $\mathrm{I}: 100$ dilution of 30 vol. $\mathrm{H}_{2} \mathrm{O}_{2}$ for $1 \mathrm{hr}$. at room temperature had no effect on its activity. It is rather easily inactivated by surface denaturation; bubbling $\mathbf{N}_{2}$ through a dilute enzyme solution for $60 \mathrm{~min}$. destroyed $40 \%$ of its activity. It can also be inactivated by incubating with dilute formalin. When kept in $50 \%$ aqueous glycerol at $2^{\circ}$, the enzyme activity remained unchanged for over 2 years. Dilute solutions of the enzyme in water or saline are rather unstable at room temperature.

\section{The haemolytic activity of Bacillus cereus lecithinase preparations}

The close association of lecithinase activity and haemolytic activity of B. cereus and B. mycoides has already been discussed (McGaughey \& Chu, 1948). One lecithinase unit is generally associated with ten haemolytic units. Further studies showed that this haemolysin has many characteristics in common with $\mathrm{Cl}$. welchii lecithinase, which is also haemolytic.

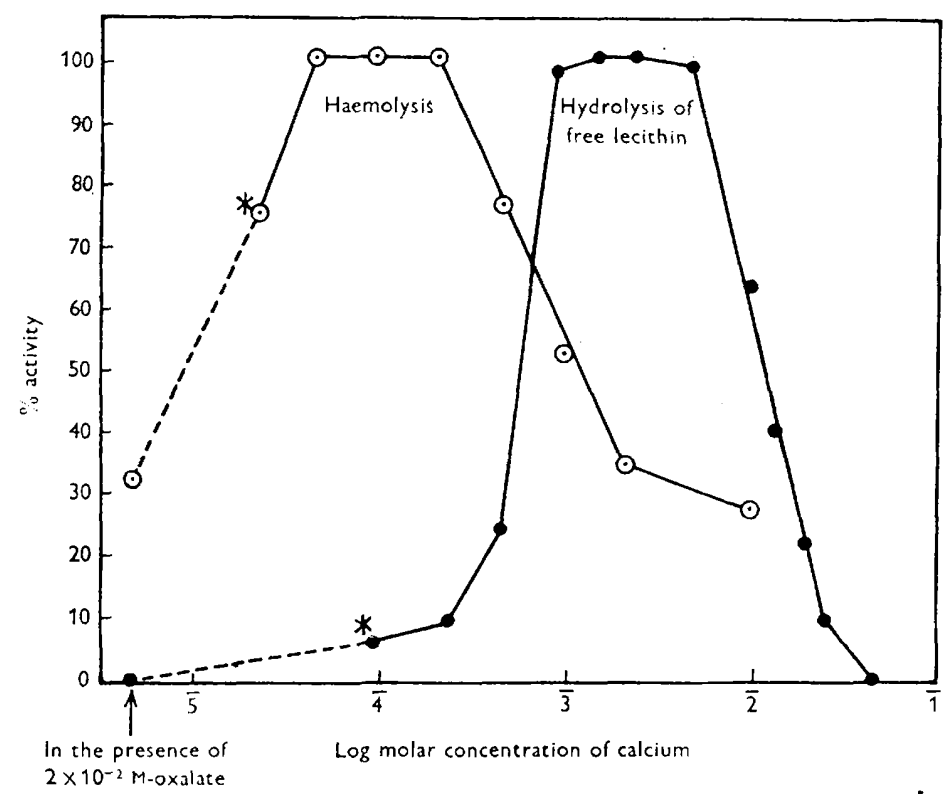

Fig. 9. The effect of $\mathrm{Ca}$ on haemolytic and lecithinase activities of $\mathrm{B}$. cereus. No Ca was added to these reaction mixtures, the small acount of Ca present as shown in the figure came from the enzyme and the substrate.

Effect of $\mathrm{Ca}$ ions. The lecithinase activity of $B$. cereus is optimal at $\mathrm{Ca}$ concentration around $1-4 \times 10^{-3} \mathrm{M}$. The haemolytic activity is maximal at a lower concentration of $\mathrm{Ca}$, ranging between $0.05-0.2 \times 10^{-3} \mathrm{M}$. The activity can be decreased either by very slight increase of $\mathrm{Ca}$ concentration or by the addition of citrate or oxalate as shown in Fig. 9. 
Susceptibility of erythrocytes of different species. Oakley \& Warrack (1941) showed that $\alpha$-toxin of $\mathrm{Cl}$. welchii was comparatively inactive against goat or horse red blood cells; $B$. cereus haemolysin behaves in the same way. Red cells of sheep, pig, rabbit, guinea-pig and man are almost equally susceptible to its action; horse cells less susceptible; and goat cells very resistant. About twenty times more haemolysin is required to haemolyse goat cells than sheep cells.

\section{Table 4. The inhibition of lecithinase activity and haemolytic activity of Bacillus cereus by normal horse serum}

Lecithinase activity : $0-0.2 \mathrm{ml}$. normal horse serum diluted with saline to $0.2 \mathrm{ml}$. were allowed to act with $1 \mathrm{ml}$. of diluted enzyme in water at $37^{\circ}$ for $15 \mathrm{~min}$., one $\mathrm{ml}$. pH $7 \cdot 1$ borate buffer, $0 \cdot 1 \mathrm{ml} .0 \cdot 1 \mathrm{M}-\mathrm{CaCl}_{2}, 0.7 \mathrm{ml} . \mathrm{H}_{2} \mathrm{O}$ and $1 \mathrm{ml} .2 \cdot 5 \%$ lecithin were then added and the amount of hydrolysis estimated in the usual way after another $15 \mathrm{~min}$. incubation.

Haemolytic activity. Decreasing amounts of normal horse serum were incubated at $37^{\circ}$ for $15 \mathrm{~min}$. with $0.1 \mathrm{mg}$. of lecithinase preparation containing $3 \mathrm{H} . \mathrm{U}$. in a total volume of $2 \mathrm{ml}$. made up with borax buffer saline. $1 \mathrm{ml}$. standard suspension of red cells were then added and the degree of haemolysis determined after $1 \mathrm{hr}$. incubation.

\begin{tabular}{|c|c|c|c|c|}
\hline \multirow[b]{2}{*}{$\begin{array}{l}\text { Amount of normal } \\
\text { horse serum (ml.) }\end{array}$} & \multicolumn{2}{|c|}{$\begin{array}{l}\text { Lecithinase activity of } 1 \mathrm{mg} . \\
\text { lecithinase preparation }\end{array}$} & \multicolumn{2}{|c|}{$\begin{array}{l}\text { Haemolytic activity of } 0.1 \mathrm{~m} \\
\text { lecithinase preparation }\end{array}$} \\
\hline & $\begin{array}{l}\text { P liberated } \\
\text { (mg.) }\end{array}$ & $\begin{array}{c}\text { Inhibition } \\
(\%)\end{array}$ & $\begin{array}{c}\text { Haemolysis } \\
(\%)\end{array}$ & $\begin{array}{c}\text { Inhibition } \\
(\%)\end{array}$ \\
\hline $1 / 5$ & 0.000 & $100 \cdot 0$ & 0 & 100 \\
\hline $1 / 10$ & 0.001 & $99 \cdot 6$ & 0 & 100 \\
\hline $1 / 20$ & $0 \cdot 004$ & $98 \cdot 5$ & 0 & 100 \\
\hline $1 / 40$ & 0.028 & $90 \cdot 0$ & 0 & 100 \\
\hline $1 / 80$ & 0.050 & $82 \cdot 5$ & 0 & 100 \\
\hline $1 / 160$ & $0 \cdot 110$ & $62 \cdot 3$ & 0 & 100 \\
\hline $1 / 320$ & $0 \cdot 156$ & $45 \cdot 0$ & 0 & 100 \\
\hline $1 / 640$ & $0 \cdot 222$ & $25 \cdot 4$ & 0 & 100 \\
\hline $1 / 1280$ & $0 \cdot 256$ & $9 \cdot 9$ & $3 \cdot 0$ & 97 \\
\hline $1 / 2560$ & - & - & $50 \cdot 0$ & 50 \\
\hline $1 / 5120$ & - & - & $97 \cdot 0$ & 3 \\
\hline 0 & 0.284 & - & $100 \cdot 0$ & - \\
\hline
\end{tabular}

Thermostability. The effect of heating on B. cereus haemolysin is interesting. The haemolytic activity was completely destroyed after heating at $60^{\circ}$ for $10 \mathrm{~min}$., while boiling for $10 \mathrm{~min}$. only destroyed $80 \%$ of its activity. This peculiar heat resistance has also been observed with staphylococcus $\alpha$-haemolysin (Arrhenius, 1907) and $\mathrm{Cl}$. welchii $\alpha$-toxin. (Guillaumie, Kreguer \& Fabre, 1946). Heating affects the haemolytic activity of $B$. cereus filtrate more than it affects the lecithinase activity. Heating at $60^{\circ}$ for $10 \mathrm{~min}$. has very little effect on lecithinase activity but completely abolishes the associated haemolytic activity. However, this does not necessarily mean that the haemolysin is unrelated to the lecithinase, as it is quite possible that heating at $60^{\circ}$ only upsets the access of lecithinase to the substrate on the red cells but does not affect the approach of the enzyme to free lecithin. The haemolytic activity of $\mathrm{Cl}$. welchii $\alpha$-toxin is also more sensitive to heat than its associated lecithinase activity.

Hot-cold effect. Unlike $C l$. welchii $\alpha$-toxin (van Heyningen, 1941 b), B. cereus haemolysin is not a hot-cold lysin. 
Resistance to oxidation. Like $C l$. welchii $\alpha$-toxin, the haemolytic activity of $\boldsymbol{B}$. cereus is not affected by oxidation.

Inhibition by normal serum. Lysis of red cells as well as hydrolysis of lecithin by $\boldsymbol{B}$. cereus are both strongly inhibited by normal sera of all the animals tested, including horse, sheep, rabbit, ox, guinea-pig, mouse and man (see below)

Effect peptone. The activity of $\boldsymbol{B}$. cereus haemolysin is greatly enhanced in the presence of a small amount of peptone. About $50 \%$ more haemolysin is required to lyse sheep red cells in the absence of peptone than in its presence. Similar observation has been made on $\mathrm{Cl}$. welchii toxin by Oakley \& Warrack (1941).

\section{Inhibition of lecithinase activity by normal serum}

The hydrolysis of free lecithin and the lysis of red blood cells by $\boldsymbol{B}$. cereus filtrate were strongly inhibited by normal sera of all the animals tested, including horse, ox, sheep, rabbit and man. The inhibitor was found to be associated with both serum globulin and serum albumin. But it was not

Table 5. The effect of normal serum proteins on the hydrolysis of free phospholipins and protein-bound phospholipins by Bacillus cereus phospholipinase

Reaction mixture: $1 \mathrm{mg}$. $B$. cereus lecithinase; $1 \mathrm{ml}$. borate buffer; $0 \cdot 1 \mathrm{ml} .0 \cdot 1 \mathrm{M}-\mathrm{CaCl}_{2}$ (only for the hydrolysis of free phospholipins); $1 \mathrm{ml}$. of $2.5 \%$ free phospholipins or $7 \%$ lipovitellenin; serum proteins as indicated above; water to $4 \mathrm{ml}$. Reaction time: $15 \mathrm{~min}$. at $37^{\circ}$.

Control. No serum protein

Horse serum globulin $0 \cdot 2 \mathrm{mg}$.

Horse serum globulin $1.0 \mathrm{mg}$.

Horse serum albumin $0.2 \mathrm{mg}$.

Horse serum albumin $1.0 \mathrm{mg}$.

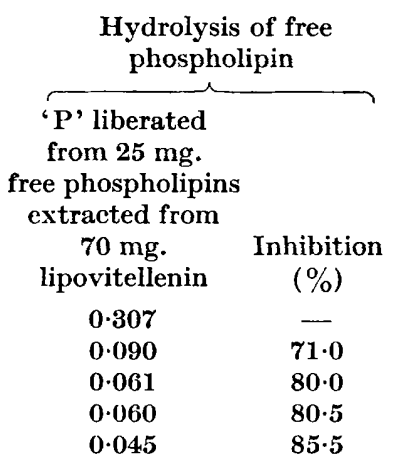

Hydrolysis of bound phospholipins

' $\mathbf{P}$ ' liberated

from $70 \mathrm{mg}$. of lipovitellenin containing about

$25 \mathrm{mg}$. bound Inhibition phospholipin (\%)

$\begin{array}{ll}0 \cdot 140 & - \\ 0 \cdot 141 & 0 \\ 0 \cdot 142 & 0 \\ 0 \cdot 141 & 0 \\ 0 \cdot 143 & 0\end{array}$

destroyed by heating to $70^{\circ}$ for $10 \mathrm{~min}$., which had apparently denatured the serum proteins. The extent of the inhibition is shown in Table 4. In the experiments cited the inhibition was measured by comparing the rate of hydrolysis during the first $15 \mathrm{~min}$. of incubation. The inhibitory effect has also been demonstrated in experiments where the reaction was allowed to proceed for several hours. The inhibition is thus not just a temporary lag effect.

It is interesting that normal serum proteins, although inhibiting the hydrolysis of free lecithin in high dilution, have very little effect on the yolk reaction. This is partially explained by the finding that normal serum proteins also fail to inhibit the hydrolysis of phospholipins bound in lipovitellenin and lipovitellin, the two egg-yolk lipoproteins (Table 5). The fact that B. cercus 
lecithinase preparation also acts on cephalin and that the cephalinase activity is not inhibited by normal serum, suggested that the acid-soluble $P$ liberated from lipovitellenin in the presence of normal serum proteins might largely come from cephalin. This possibility was ruled out, however, by the finding that the choline contents of the acid-soluble $\mathbf{P}$ compounds liberated from lipovitellenin in the presence of normal serum proteins or in its absence were practically the same. The reason why the combination of lecithin with proteins like vitellenin or vitellin should counteract the inhibition of the lecithinase by serum protein is not clear.

\section{Production of specific anti-lecithinase in rabbits and its differentiation from normal serum inhibitor}

Specific $B$. cereus anti-lecithinase has been produced by immunizing rabbits with the enzyme preparation. Unlike the inhibitor in normal serum the specific anti-lecithinase is capable of inhibiting not only the hydrolysis of free lecithin but also the yolk reaction and the hydrolysis of protein-bound lecithin. Possibly, the specific anti-lecithinase has a more direct effect on the enzyme than the inhibitor present in normal serum. Table 6 compares the effect of normal rabbit serum and immune rabbit serum on various activities on $B$. cereus lecithinase preparation.

\section{Table 6. The effect of normal rabbit serum and immune rabbit serum on various activities of Bacillus cereus lecithinase preparation}

This table compares the effects of $0.1 \mathrm{ml}$. normal serum and $0.1 \mathrm{ml}$. immune serum on the various activities produced by $1 \mathrm{mg}$. of $\boldsymbol{B}$. cereus lecithinase preparation.

Lecithinase activity

\begin{tabular}{|c|c|c|c|c|c|c|}
\hline \multirow{2}{*}{\multicolumn{2}{|c|}{ - }} & \multicolumn{2}{|c|}{$\begin{array}{c}\text { Hydrolysis of free } \\
\text { lecithin }\end{array}$} & \multicolumn{3}{|c|}{$\begin{array}{l}\text { Hydrolysis of phospholipins } \\
\text { bound in lipovitellenin }\end{array}$} \\
\hline & & $\begin{array}{l}\text { P liberated } \\
(\mathrm{mg} .)\end{array}$ & $\begin{array}{c}\text { Inhibition } \\
(\%)\end{array}$ & P lib & $\begin{array}{l}\text { perated } \\
\text { mg.) }\end{array}$ & $\begin{array}{l}\text { Inhibition } \\
\qquad(\%)\end{array}$ \\
\hline Control (no serum) & & $0 \cdot 310$ & - & & $\cdot 140$ & $\dot{-}$ \\
\hline Normal serum $0.1 \mathrm{r}$ & $\mathrm{ml}$. & 0.005 & 98 & & $\cdot 140$ & 0 \\
\hline \multirow[t]{3}{*}{ Immune serum $0 \cdot 1$} & $1 \mathrm{ml}$ & $0 \cdot 005$ & 98 & & $\cdot 055$ & 61 \\
\hline & \multicolumn{2}{|c|}{ Haemolytic activity } & \multicolumn{2}{|c|}{ Yolk reaction } & \multicolumn{2}{|c|}{ Toxicity } \\
\hline & $\begin{array}{c}\text { Haemolysis } \\
(\%)\end{array}$ & $\begin{array}{c}\text { Inhibition } \\
(\%)\end{array}$ & $\begin{array}{l}\text { Increase of In } \\
\text { turbidity }\end{array}$ & $\begin{array}{l}\text { nhibition } \\
(\%)\end{array}$ & $\frac{\text { mice dying }}{\text { mice tested }}$ & $\begin{array}{l}\text { Protection } \\
(\%)\end{array}$ \\
\hline Control (no serum) & 100 & - & $168^{*}$ & - & $12 / 12$ & - \\
\hline Normal serum $0.1 \mathrm{ml}$. & 0 & 100 & 167 & 0 & $12 / 12$ & 0 \\
\hline Immune serum $0.1 \mathrm{ml}$ & 0 & 100 & 8 & 95 & $3 / 12$ & $7 \tilde{5}$ \\
\hline
\end{tabular}

Antisera against $B$. cereus lecithinase have no effect on $C l$. welchii lecithinase, and vice versa; the enzymes therefore are antigenically different. On the other hand, lecithinase produced by $\boldsymbol{B}$. mycoides can be neutralized by antisera against $B$. cereus lecithinase. This provides further evidence of their close relationship. 


\section{The toxicity of Bacillus cereus lecithinase}

The fact that the hydrolysis of free lecithin and lysis of red blood cells by $B$. cereus lecithinase are inhibited by normal serum suggests that the enzyme might be innocuous in vivo. On the other hand the inability of normal serum to inhibit the hydrolysis of lecithin bound in egg-yolk lipoprotein suggests that normal serum might fail to inhibit the action of the enzyme on other lipoproteins occurring in animal tissue; the enzyme might therefore not be so innocuous in vivo as first expected. In fact, the enzyme preparation was found to be toxic for experimental animals, although the toxicity might be due to factors other than lecithinase.

Intravenous inoculation of a dose of the enzyme preparation containing 2-4 lecithinase units is lethal to mice. The M.L.D. of $C l$. welchii $\alpha$-toxin for mice, on the other hand, generally contains 0.5 lecithinase unit. Intradermal injection in rabbits and guinea-pigs produces marked inflammatory lesions with central necrosis. The toxicity can be neutralized by immune rabbit sera containing specific anti-lecithinase. As the enzyme preparation is very crude, it is impossible to say whether its toxicity is due to lecithinase activity exclusively or to some other factors as well. The enzyme preparation has already been found to possess cephalinase activity which is likely to account for part of its toxicity.

\section{The action of Bacillus cereus lecithinase preparation on cephalin}

Unlike the $\mathrm{Cl}$. welchii lecithinase (Macfarlane, 1942) the preparation from $B$. cereus was capable of hydrolysing not only lecithin but also cephalin. Whether the hydrolysis of cephalin is due to the lecithinase or to another enzyme remains to be seen. A few preliminary experiments have shown that acid-soluble organic $\mathbf{P}$ but not inorganic $\mathbf{P}$ is split from cephalin by the enzyme. An enzyme preparation containing three lecithinase units was able to catalyse the production of $0.12 \mathrm{mg}$. acid-soluble $P$ from $25 \mathrm{mg}$. of cephalin in 15 min. under the same conditions as used for lecithinase estimation. The cephalinase activity also requires the presence of $\mathrm{Ca}$ ion, but is not inhibited by normal serum, which has a very strong inhibitory effect on the lecithinase activity.

\section{DISCUSSION}

The data showing the close similarity of $B$. cereus and $\mathbf{C l}$. welchii lecithinases in their enzymic properties and biological activities are summarized in Table 7 . $B$. cereus lecithinase possesses most of the biological activities found to be associated with $\mathrm{Cl}$. welchii $\alpha$-toxin. Although these two lecithinases are very similar in most respects, differences have been noted between them. Some of these differences may have a bearing on their activities in vivo; the different reactions to normal serum is an interesting example. Thus, although these two enzymes exhibit similar chemical activities in vitro, they might differ very much in their activities in vivo.

The inhibitory action of normal serum protein on the hydrolysis of free 
lecithin by $\boldsymbol{B}$. cereus lecithinase, in contrast to its failure to suppress the hydrolysis of lecithin bound in egg-yolk lipoproteins is another illustration of the complexity of the biological system.

Table 7. Comparison of Bacillus cereus lecithinase and Clostridium welchii lecithinase

$\begin{array}{ll}\begin{array}{c}\text { Lecithinase } \\ \text { activity }\end{array} & \begin{array}{l}\text { Ca requirement } \\ \text { Optimal } \mathrm{pH}\end{array} \\ & \text { Thermostability }(\%): \\ & \text { activity after }\left\{\begin{array}{l}60^{\circ} \quad 10 \mathrm{~min} . \\ \text { boiling } 10 \mathrm{~min} .\end{array}\right. \\ & \text { Resistance to oxidation } \\ \text { Inactivation by formalin } & \text { Precipitation by } 2 / 3 \text { sat'd. }\left(\mathrm{NH}_{4}\right)_{2} \mathrm{SO}_{4} \\ & \text { Activity on egg-yolk lipoproteins } \\ & \text { Inhibition by normal serum proteins } \\ \text { Biological } & \text { Egg-yolk reaction and Nagler reaction } \\ \text { activity } & \text { Haemolytic activity } \\ & \text { Inhibition of haemolysis by normal serum proteins } \\ & \text { Dermonecrotic effect in guinea-pigs } \\ & \text { Toxicity to mice }\end{array}$

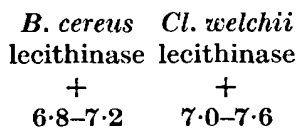

I wish to express my gratitude to Prof. C. A. McGaughey and Prof. W. I. B. Beveridge for their interest and encouragement in this work; and to Dr W. E. van Heyningen and Dr Dorothy Needham for their advice and help and for reading the manuscript. My thanks are also due to Dr M. G. Macfarlane for her supply of the monophosphatase.

\section{REFERENCES}

Alderton, G. \& Fevold, H. L. (1945). Preparation of the egg yolk lipoprotein, lipovitellin. Arch. Biochem. 8, 415.

Arrhenrus, S. (1907). Immunochemie. Akad verlagsgesell. Leipzig.

Fevold, H. L. \& Lausten, A. (1946). Isolation of a new lipoprotein, lipovitellenin, from egg yolk. Arch. Biochem. 11, 1.

GuICK, D. (1944). Concerning the reineckate method for the determination of choline. J. biol. Chem. 156, 643.

Guillaumie, M., Kreguer, A. \& Fabre, M. (1946). Proprietés et composition de la toxine de Welchia perfringens. I. Action hémolytique. Ann. Inst. Pasteur, 72, 12.

Herbert, D. (1941). A simple colorimetric method for the estimation of haemolysis and its application to the study of streptolysin. Biochem. J. 35, 1116.

Heyningen, W. E. van (1941 a). Estimation of the $\alpha$-toxin of $\mathrm{Cl}$. welchii, type A. Biochem. J. 35, 1246.

Heyningen, W. E. van (1941 b). Partial purification of the toxins of $\mathrm{Cl}$. welchii, type A. Separation of $\alpha$ and $\theta$ toxins. Biochem. J. 35, 1257.

KInG, E. J. (1946). Micro-analysis in medical biochemistry, 1st ed. London: J. and A. Churchill, Ltd.

Macfarlane, M. G. \& KNight, B. C. J. G. (1941). The biochemistry of bacterial toxins. 1. The lecithinase activity of $C l$. welchii toxins. Biochem. J. 35, 884.

MaCfarlane, M. G. (1942). Specificity of the lecithinase present in $\mathrm{Cl}$. welchii toxin. Biochem. J. 36, iii.

McGaughey, C. A. \& Ciru, H. P. (1948). The egg yolk reaction of aerobic sporing bacilli. J. gen. Microbiol. 2, 334. 
Maclean, H. \& Maclean, I. S. (1927). Lecithin and allied substances of the lipins, 2nd ed. London: Longmans, Green and Co. Ltd.

OAKLeY, C. L. \& Warrack, G. H. (1941). Factors affecting the activity of the $\alpha$-toxin of Clostridium zeelchii. J. Path. Bact. 53, 335.

WeLCH, E. A. (1945). The fractionation of lecithin and cephalin. J. biol. Chem. $161,65$.

Zamecnik, P. C., Brewster, L. E. \& Lipmann, F. (1947). A manometric method for measuring the activity of the $\mathrm{Cl}$. welchii lecithinase and a description of eertain properties of the enzyme. J. exp. Med. 85, 381.

(Received 17 September 1948) 